\title{
Nobel committee rewards pioneers of development studies in fruitflies
}

London. 'The 1995 Nobel Prize for physiology or medicine has been awarded to three developmental biologists - including one of research on how genes control early embryonic development in the fruitfly, Drosophila melanogaster. They demonstrated that a genetic approach can be successfully used as a way of studing the development of a complex organism.

The \$1-million prize will be shared between Edward B. Lewis, professor emeritus at the California Institute of Technology, Christiane Nüsslein-Volhard, from the Max Planck Institute for Developmental Biology in Tübingen, Germany, and Eric F. Wieschaus, Squibb Professor of Molecular Biology at Princeton University.

For Lewis, now 77 but still an active researcher, the Nobel Prize caps a lifetime's work in developmental genetics - he is widely considered to be the first person to have applied genetic tools to the study of embryo development - that began at the California Institute of Technology in the early 1940 s.

An immensely popular scientist, Lewis was both characteristically modest and magnanimous about the award. "My contribution was not any more important than those of my coworkers, among them my wife Pamela, who isolated one of the important mutants," he says. "We just tried to push the genetics as hard as we could for 50 years, being convinced that they can help us to understand development."

Eric Wieschaus, now 48, but once a "young scientist, just thrilled to be in the lab and excited to do experiments", says that the thought he might eventually win the Nobel Prize never crossed his mind. "The real significance of the work started to become apparent to us in about 1980," he adds.

Wieschaus says that one of the lessons of the award is that it illustrates how it is seldom clear what a piece of scientific information is going to be valuable for - but often most of it turns out useful. "Looking back the discipline's original pioneers - for

we knew the experiments were important and wonderful - maybe even Nobel-worthy - but there are many such experiments and not all are rewarded."

He adds: "We were in a very privileged position in Heidelberg, able to do experiments without having to immediately justify them. Most young people today don't have the same luxury."

Nüsslein-Volhard, 52, had previously been tipped for the prize. "But when it came, it was a surprise." Her

\section{IMAGE UNAVAILABLE FOR COPYRIGHT REASONS}

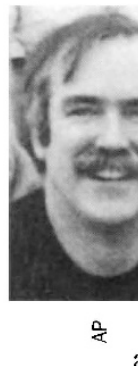

analysing a large number of these mutants would eventually lead to major insights into how a complex body pattern is generated.

The mutated genes responsible for the transformation were found to be members of an entire family, the bithorax complex. Genes at the beginning of the complex were found to control anterior body segments, while genes further down the genetic map controlled more posterior body segments. $\mathrm{He}$ published a key paper in 1978 (see Nature 276, 565-570) introducing his concepts to a wider audience for the first time.

This audience included Nüsslein-Volhard and Wieschaus, both at the European Laboratory for Molecular Biology at Heidelberg. The researchers knew of a few existing mutations which disrupt the embryonic body plan. They felt a need to isolate as many mutants as possible to understand the whole process of embryonic pattern formation.

When they began their work, success was not immediately certain. But several years later, they identified a relatively small number of genes responsible for specific defects (see Nature 287, 795-801; 1980). "It was clear that genes somehow controlled this process," says Wieschaus.

"What we set out to do was to identify which genes." Forty-thousand random mutations were observed. Most had only minor effects on development. "But there were 150 cases or so where extraordinary things would happen," says Wieschaus.

Gerd Jürgens, professor of developmen-

comments echo the widely-held view among biologists that a prize in developmental biology was long overdue, particularly as the key research was performed over a decade ago.

Analysis of the fruit fly Drosophila dates back to the beginning of the century when the first mutations were discovered. By the 1940 s it had found in Lewis an inspired young researcher willing to invest time and effort into analysing the genetic basis for a particular class of mutations, so-called homeotic transformations which cause substitution of one segment of the body with a different one. Lewis was convinced that

\section{CREST rides a wave of popularity in Brussels}

Brussels. Europe's Council of Ministers has agreed to enhance the political and strategic role of the European Commission's Scientific and Technical Research Committee (CREST), recently under fire for concentrating excessively on administrative issues.

The new functions of CREST will include responsibility for coordinating research funded by the European Union with that of the union's 15 member states, and for the dissemination and use of research results. But the council has rejected a suggestion put forward by France that responsibility for CREST should be taken away from the commission and placed in the hands of the country holding the presidency of the council (see Nature 373, 276; 1995). tal genetics at Tübingen University and a former postdoctoral student with NüssleinVolhard and Wieschaus, says the three had made an outstanding contribution and were worthy winners. An "ecstatic" Kathryn Anderson, a researcher at the Department for Molecular and Cellular Biology at the University of California at Berkeley, says "this is the right combination of people and its a wonderful statement for the importance of basic research".

Peter Lawrence, a geneticist at the Laboratory for Molecular Biology in Cambridge, describes the trio as "role models for scientists of the future". The award, he adds, is a much-needed signal to science policy makers of the need to continue funding unfashionable, risk-laden, long-term projects whose result is not always in sight.

This research, Lawrence says, is the type of work that should be every scientist's bread and butter, but is becoming more and more difficult to achieve. "I am convinced that $\mathrm{Ed}$ Lewis would not have got a grant in our days," he says.

Barbara Cohen 